\title{
SPHERICAL PRIMARY MIRROR IN TELESCOPES WITH COMPLEX (MULTI-ELEMENT) OPTICAL DESIGNS
}

\author{
S. V. Podlesnyak, N. N. Fashchevsky, Yu. N. Bondarenko, S. M. Andrievsky \\ Astronomical Observatory, Odessa National University, Ukraine
}

\begin{abstract}
An optical design for telescope with spherical primary mirror, planoidal surface and two-lens corrector is discussed. The spherical mirror has an aperture ratio $1 / 2.69$. After reflection from the spherical mirror, the wave front falls on a planoidal surface and "forms" the reflected wave front from a virtual mirror with $\mathrm{e}^{2}=1.576$. After passing the two-lens corrector, the light is collected in the focal plane. A dot diagram in the focal plane shows that all three-order aberrations are successfully corrected. The effective field of view is 2 degrees. The aperture ratio is $1 / 2.28$.
\end{abstract}

АНОТАЦІЯ. В загальному вигляді оптичні схеми, які обговорюються в статті, базуються на використанні головного дзеркала зі сферичною поверхнею $\mathrm{e}^{2}=0 \mathrm{i}$ вторинного планоїдного дзеркала 3 поверхнею великих порядків близькою до пласкої поверхні. Хвилевий фронт від головного дзеркала трансформується планоїдом таким чином, якби він був відбитий деяким віртуальним дзеркалом 3 наперед заданим ексцентриситетом. Для попереднього виявлення можливостей такого рішення були розглянуті схеми телескопів з головним дзеркалом, діаметр якого складає 60 см. Такий вибір був обумовлений тим, що у нас існують оптичні дизайнерські рішення для телескопів із дзеркалами вказаного діаметра.

Запропонована, як найбільш приваблива для реалізації в Астрономічній обсерваторії Одеського національного університету, оптична конструкція телескопа iз головним сферичним дзеркалом, планоїдним дзеркалом і двохлінзовим коректором. Сферичне дзеркало має світлосилу 1/2.69. Після відбиття світла від сферичного дзеркала фронт хвиль падає на планоїдну поверхню і «формує» фронт хвилі, уявно відбитої віртуальним дзеркалом $3 \mathrm{e}^{2}=1.576$. Після проходження двохлінзового коректора світло збирається у фокальній площині. Точкова діаграма в фокальній площині показує, що всі аберації третього порядку практично виправлені. Ефективне поле зору становить 2 градуси на пласкій фокальній поверхні. Ефективна світлосила для телескопа такої системи становить $1 / 2.28$.
Таким чином, ми описали ширококутову систему 3 не досить малою апертурою, яка $є$ схожою 3 так званою оптичною системою "Нyperbolic-Ross". Основна відмінність тут полягає в тому, що остання оптична схема базується на первинному дзеркалі, яке має форму гіперболоїда, в той час як в першій використовується сферичне дзеркало.

Пропонується, що таке рішення може бути актуальним для телескопів 3 діаметром головного дзеркала 1 м і більше, а також для сегментних дзеркал. Така система 3 дзеркалом $(1-1.5)$ м може буде виготовлена на Астрономічній обсерваторії Одеського національного університету і доповнить мережу іi оптичних інструментів.

Key words: telescope optical schemes

\section{Introduction}

The proposed telescope optical designs consist of two components (Figure 1): a spherical primary mirror (indicated as 1) $\mathrm{e}^{2}=0$ and a secondary planoidal mirror (indicated as 2) with nearly flat (planar) high-order surface.

The planoidal mirror surface is calculated so that the wave front converging onto the focal plane (indicated as 3 ) is modified as if it is reflected from some virtual mirror with preliminary set parameters rather than from a spherical mirror. This enables us to employ different optical layouts while using a spherical mirror as the primary one.

A special computer programme to calculate the meridional surface profile of the secondary mirror, taking into account all the preliminary set parameters of the virtual mirror, has been developed based on [2,3]. Note that there is no analytic expression, but just a numerical table of co-ordinates for the points along the meridional surface profile of the planoidal surface with a given increment. These data are quite sufficient to manufacture such a surface. 


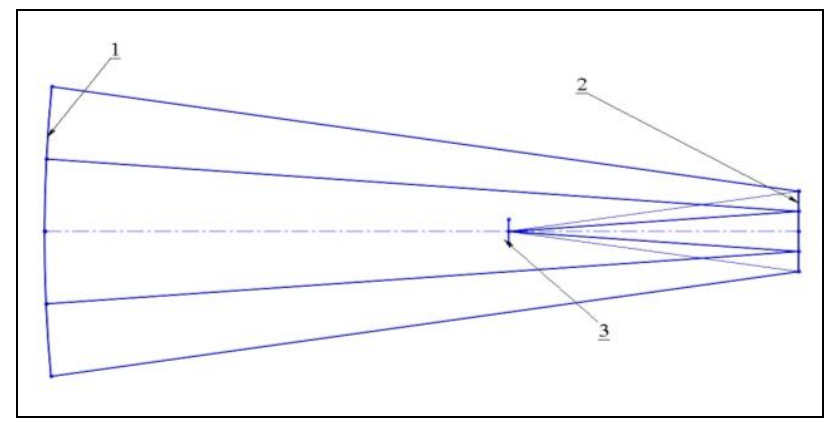

Figure 1: Proposed telescope optical design: 1- spherical mirror, 2- planoidal mirror, 3- focal plane.

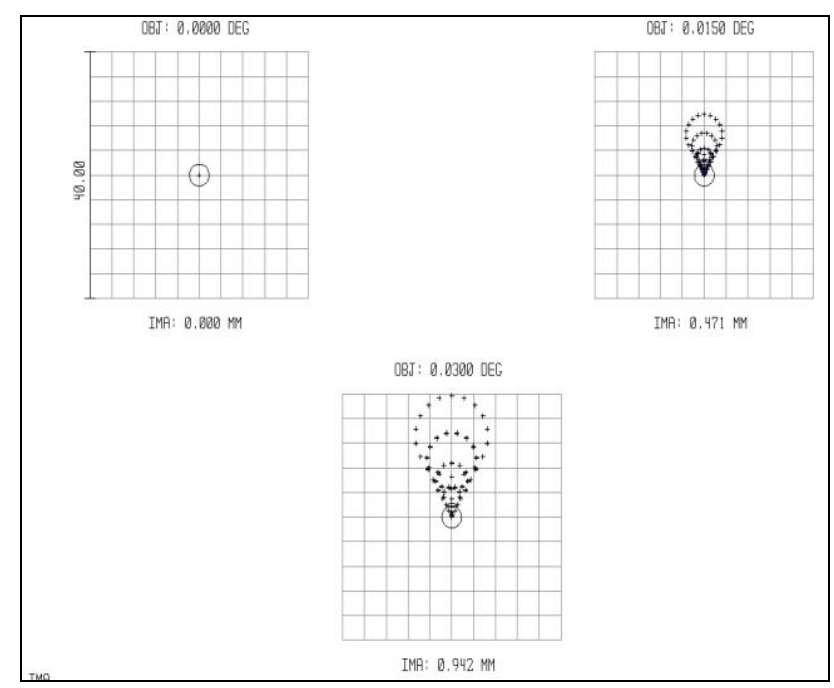

Figure 3: A dot diagram

\section{The text of the proposed optical design}

In order to test the proposed optical designs, we chose a spherical mirror which is $60 \mathrm{~cm}$ in diameter with the standard light-gathering power of $1 / 3$. Such a choice was mainly due to the fact that there had been already optical design solutions for $60 \mathrm{~cm}$ mirror blanks.

Figure 2 illustrates the simplest example of correcting the spherical aberration of the primary mirror.

The wave front after reflection from the spherical mirror (1) on the planoidal surface (2) is turned into the wave front from a virtual parabola (3) with the same lightgathering power; thus, an astigmatic image with corrected spherical aberration is formed on the axis in the focal plane (4). A dot diagram (Figure 3) depicts the effect of the field of view on the image quality.

The centre diffraction image is distorted by a significant comatic aberration towards the edges as must be the case. Therefore, the effective field of view is limited to about 10 arc minutes.

Using the same principles, we have demonstrated that is feasible to produce the Ritchey-Chrétien aplanatic

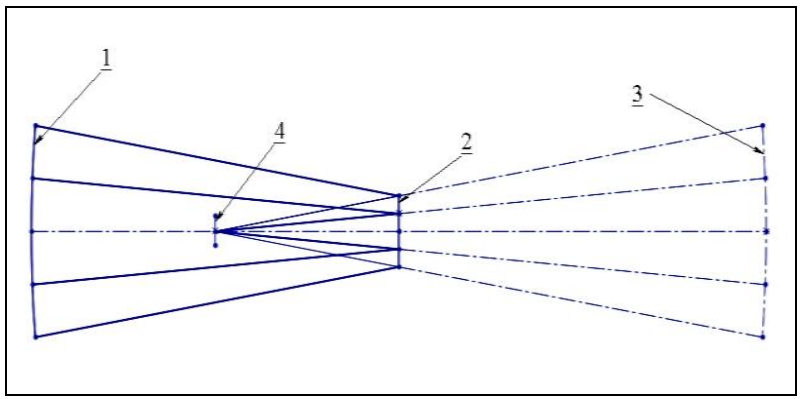

Figure 2: The simplest example of correcting the spherical aberration of the primary mirror: 1- primary spherical mirror, 2 - planoidal surface, 3 - virtual parabolic mirror, 4 - focal plane.

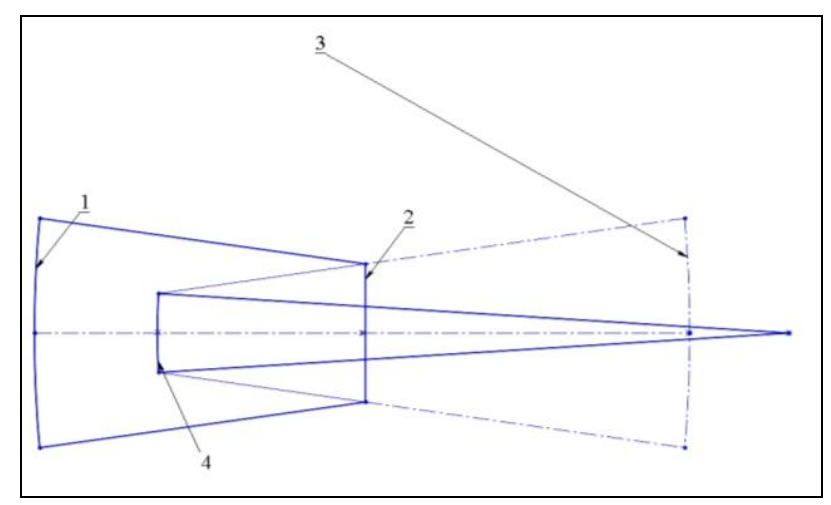

Figure 4: Optical layout elements: 1 - spherical primary mirror, 2 - planoidal mirror, 3 - virtual hyperbolic mirror, 4 - third small hyperbolic mirror.

design with a spherical primary mirror, equivalent lightgathering power of $1 / 8$ and effective field of view of 0.75 degrees. Though such a layout is of no practical importance due to a long length of the tube in such an optical design, it has been presented here to exemplify all the opportunities for applying the suggested method. Figure 4 shows the following optical layout elements: a spherical primary mirror (1), the planoidal surface (2), a virtual hyperbolic mirror (3) with $\mathrm{e}^{2}=1.01$ and the third small hyperbolic mirror with $\mathrm{e}^{2}=6.537$.

\section{Three-mirror telescope}

Three-mirror telescope (Figure 5), whose parameters were calculated by N.N.Faschevsky [4] using a different method, belongs in this type of optical systems. Its optical design consists of a spherical primary mirror (1), the planoidal surface (2) and the third elliptical mirror with $\mathrm{e}^{2}$ $=0.563$. The wave front after reflection from the spherical mirror (1) on the planoidal surface (2) is turned into the wave front from a virtual elliptical mirror (3) placed at a given distance. 


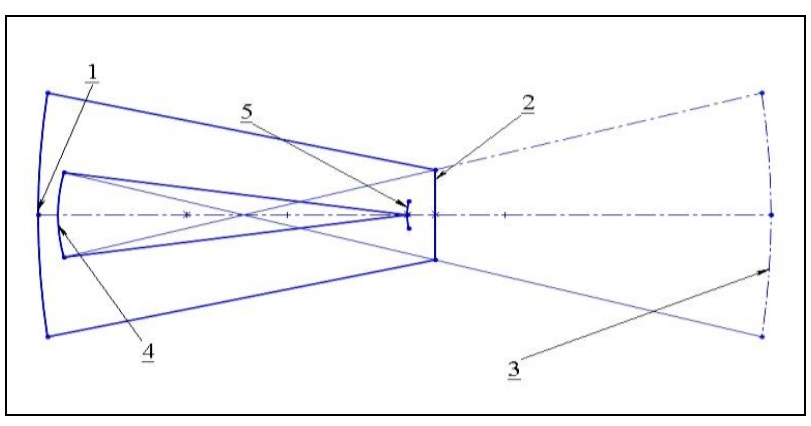

Figure 5: Three-mirror telescope: 1 - spherical primary mirror, 2 - planoidal mirror, 3 - virtual elliptical mirror, 4 - the third elliptical mirror, 5 - the focal plane.

According to the classification by D.D. Maksutov [1], the virtual and elliptical mirrors form a lengthening postfocal aplanatic system. A dot diagram (Figure 6) depicts the effect of $1.5^{\circ}$ field of view on the image quality. Both comatic and astigmatic aberrations are well corrected, but the focal plane remains curved (indicated as 5 in Figure 5). Such a telescope was built at Odesa Astronomical Observatory and produced high-quality images; however, for some reason, the telescope's lifetime turned out to be short.

\section{Optical scheme with a two-lens corrector}

Figure 7 presents a telescope with a two-lens corrector. It uses a spherical primary mirror with the light-gathering power $1 / 2.69$ (1), the planoidal surface (2) and a corrector (4). The wave front after reflection from the primary mirror (1) on the planoidal surface (2) is turned into the wave front from a virtual mirror (3) with $\mathrm{e}^{2}=1.576$, thus, an image is formed in the focal plane (5). A dot diagram of the system is presented in Figure 8; as can be seen, all third-order aberrations are well corrected, the effective field of view is 2 degrees with resolution over a flat focal surface with the light-gathering power 1/1.28.

\section{Conclusion}

Summarizing, we described a wide-field instrument which is analogous to our earlier calculated telescope optical design named "Hyperbolic - Ross" [5], but unlike the latter the new instrument uses a spherical primary mirror rather than hyperbolic one.

This optical layout appears to be the best practical out of all optical designs discussed above. There are some disadvantages of such systems - an increased light loss due to a large obscuration or additional reflection; moreover, most designs imply internal placement of the light detector. However, all these disadvantages can be minimised with the proper optimisation of the optical system.

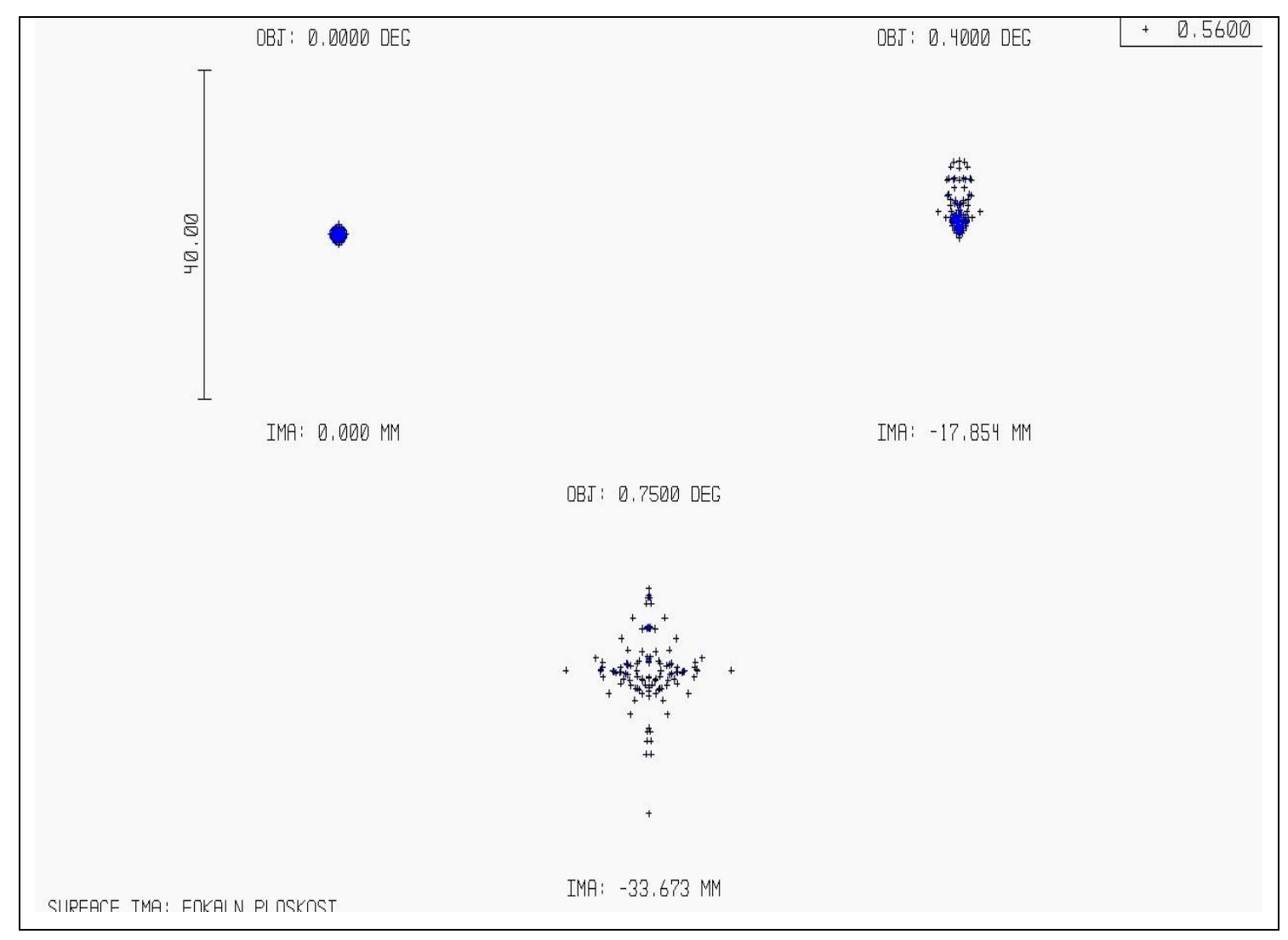

Figure 6: A dot diagram (see text) 


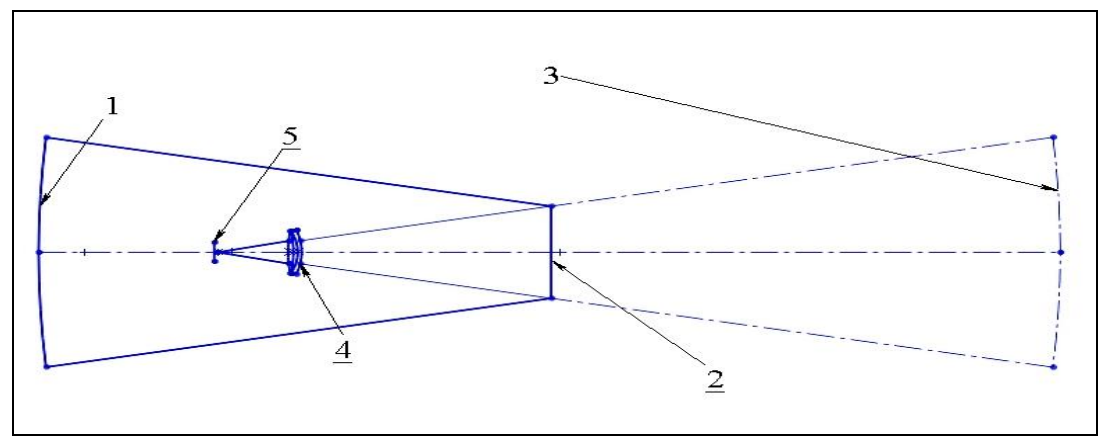

Figure 7: Telescope with a two-lens corrector:

1 - spherical mirror, 2 - planoidal mirror, 3 - virtual mirror, 4 - two-lens corrector, 5 - focal plane.

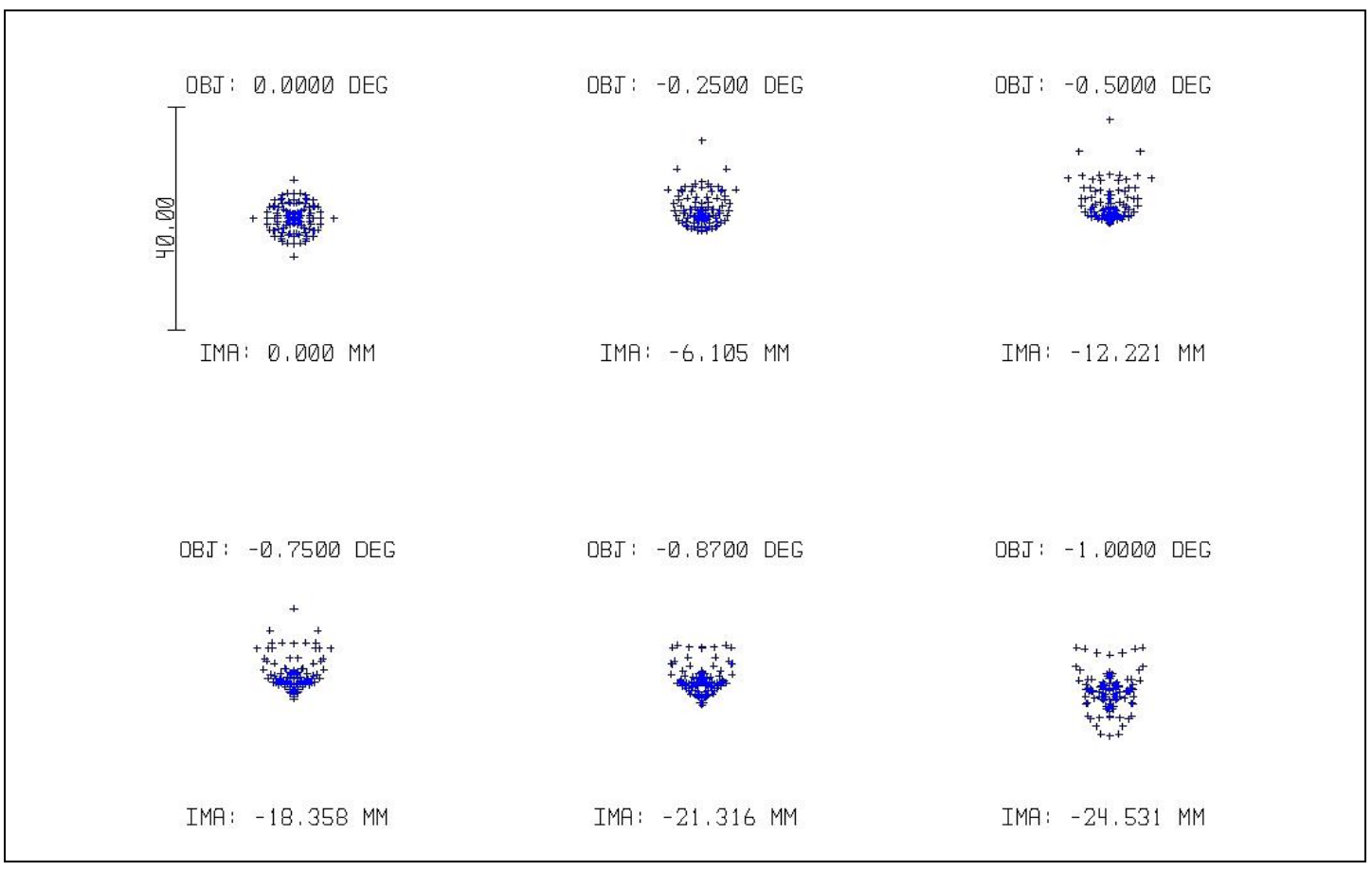

Figure 8: A dot diagram of the system showed in Fig. 7

Such optical designs are of no particular interest for telescopes with a $60 \mathrm{~cm}$ mirror; however, with increasing diameter of mirrors, the importance of such optical layouts is being reinforced, especially for segmented-mirror telescopes, for which both the working surface of each segment and the shape of the array of mirrors should be spherical.

In the future, it is planned to implement the proposed optical scheme in the network of optical instruments of Astronomical Observatory of Odessa National University.

\section{References}

1. Maksutov D.D. Astronomical optics. Lviv: Nauka, 1979, $395 \mathrm{p}$.
2. Michelson N.N. Astronomical telescope optics and methods for its calculation. Moscow: Physmathlit, 1995, $333 \mathrm{p}$.

3. Popov G.M. Aspheric surfaces in astronomical optics. Moscow: Nauka. Chief editorial board for physical and mathematical science literature, 1980, $160 \mathrm{p}$.

4. Fashchevsky N.N.: 1988, PhD Thesis in Physical and Mathematical Sciences, Odessa State University, Odessa.

5. Fashchevsky N.N., Podlesnyak S.V., Bondarenko Yu. N., Andrievsky S.M., Romanyuk Ya. O.: 2020, Odessa Astron. Publ., 33, 97. 